\title{
Improvement of high-temperature oxidation resistance to water vapor by alumina coating on beta-sialon ceramic
}

\author{
Hajime Kiyono, Yasunobu Noritake and Shiro Shimada \\ Graduate School of Engineering, Hokkaido University, Sapporo 060-8628, JAPAN, \\ FAX: +81-11-706-6578, e-mail: kiyono@eng.hokudai.ac.jp
}

To improve oxidation resistance to water vapor in high-temperature environment, alumina $\left(\mathrm{Al}_{2} \mathrm{O}_{3}\right)$ film is coated on $\beta$-sialon $(\mathrm{z}=3)$ ceramic. Aluminum alkoxide $\left(\mathrm{Al}(\mathrm{OBt})_{3}\right)$ with diethanolamine and ethanol and $\mathrm{Al}_{2} \mathrm{O}_{3}$ sol with ethanol were used as precursor solutions. These precursors were coated on $\beta$-sialon substrate by dip coating method and the coated sample was heated at $600^{\circ} \mathrm{C}$ for $1 \mathrm{~h}$ (as-coated sample). The as-coated sample was heat-treated at $1300^{\circ} \mathrm{C}$ in $\mathrm{Ar} / \mathrm{O}_{2}(95 / 5 \mathrm{vol} \%$ ) for $2 \mathrm{~h}$ and subsequently treated in $\mathrm{Ar}$ for $10 \mathrm{~h}$ (heat-treated sample). The samples were oxidized in $\mathrm{Ar} / \mathrm{O}_{2} / \mathrm{H}_{2} \mathrm{O}(8 / 2 / 90 \mathrm{vol} \%)$ at $1200^{\circ} \mathrm{C}$ for $\sim 100 \mathrm{~h}$. The heat-treated samples showed high oxidation resistance to water vapor comparing with as-coated sample.

Key words: sialon, alumina, oxidation, water vapor, coating

\section{INTRODUCTION}

Because of excellent mechanical properties, good oxidation resistance in high temperature condition and high thermal shock resistance, Si-Al-O-N (sialon) ceramics have been promising high-temperature structural materials for components of engines or gas turbines. ${ }^{1}$ Generally high oxidation resistance of silicon based non-oxide ceramic to dry oxygen is achieved by the presence of protective surface layer based on amorphous $\mathrm{SiO}_{2} .1,2$ In atmosphere containing water vapor, however, the silicon based non-oxide ceramics are easily oxidized, because a large amount of water comparing with oxygen is able to dissolve in amorphous $\mathrm{SiO}_{2}$ and oxidizes the ceramics. ${ }^{3-6}$ Therefore, for the application in high-temperature and high $P_{\mathrm{H} 2 \mathrm{O}}$ conditions, environmental barrier coating (EBC) to water vapor is needed. Alumina $\left(\mathrm{Al}_{2} \mathrm{O}_{3}\right)$ and mullite $\left(3 \mathrm{Al}_{2} \mathrm{O}_{3} 2 \mathrm{SiO}_{2}\right)$ have been utilized as barrier coating materials because of high chemical stability and mechanical properties. ${ }^{7}$ In the mullite-coated ceramics, delamination between the coating and substrate due to poor adherence brings about an issue to overcome. ${ }^{7}$ To develop adhesivity of mullite coating, it is reported that alumina was coated on $\mathrm{Si}_{3} \mathrm{~N}_{4}$ ceramic and was transformed to mullite by reaction between the coated alumina and $\mathrm{SiO}_{2}$, which is formed by oxidation of $\mathrm{Si}_{3} \mathrm{~N}_{4}$ ceramic. ${ }^{8}$

It is known that $\beta$-sialon $\left(\mathrm{Si}_{6-\mathrm{z}} \mathrm{Al}_{\mathrm{z}} \mathrm{O}_{\mathrm{z}} \mathrm{N}_{8-\mathrm{z}}, \mathrm{z}=0 \sim 4.2\right)$ ceramics produces mullite and silica by oxidation at high-temperature condition. ${ }^{1,5,9}$ In case of $\beta$-sialon with $\mathrm{z}=3$, oxidation by $\mathrm{O}_{2}$ is written as follows;

$2 \mathrm{Si}_{3} \mathrm{Al}_{3} \mathrm{O}_{3} \mathrm{~N}_{5}+7.5 \mathrm{O}_{2}$

$\rightarrow 3 \mathrm{Al}_{2} \mathrm{O}_{3} \cdot 2 \mathrm{SiO}_{2}+4 \mathrm{SiO}_{2}+5 \mathrm{~N}_{2}$

In the present study, alumina film was fabricated by dip-coating method of alumina precursors. To control crystallinity and to improve adhesivity of alumina coating, the coated samples were heat-treated in the oxidative atmosphere to form mullite at the interface between $\beta$-sialon substrate and $\mathrm{Al}_{2} \mathrm{O}_{3}$ coating by a reaction between the coated alumina and silica

$3 \mathrm{Al}_{2} \mathrm{O}_{3}+2 \mathrm{SiO}_{2} \rightarrow 3 \mathrm{Al}_{2} \mathrm{O}_{3} \cdot 2 \mathrm{SiO}_{2}$

where $\mathrm{SiO}_{2}$ is produced by oxidation of $\beta$-sialon in reaction (1).

\section{EXPERIMENTAL PROCEDURE}

Sintered $\beta$-sialon was fabricated by hot-pressing of $\beta$-sialon $\left(\mathrm{z}=3\right.$ ) powder without additive at $1900^{\circ} \mathrm{C}$ and at $24 \mathrm{MPa}$ for $4 \mathrm{~h}$ in $\mathrm{N}_{2}$ atmosphere. Relative density of the sintered compact was about $96 \%$. The sintered $\beta$-sialon was cut to specimens of $15 \times 5 \times 2 \mathrm{~mm}^{3}$ in size and the surface was polished. An aluminum alkoxide precursor solution (AK sol) was prepared by dissolving aluminum tri-sec-butoxide $\left(\mathrm{Al}(\mathrm{OBt})_{3}\right.$, Kanto chemical) in a mixture of diethanolamine (DEA, Kanto chemical) and ethanol. The molar ratio of $\mathrm{Al}(\mathrm{OBt})_{3}: \mathrm{DEA}: \mathrm{EtOH}$ was 1:1.5:10. $\quad \mathrm{Al}_{2} \mathrm{O}_{3}$ sol precursor solution (CA sol) was prepared by dissolving commercially available $\mathrm{Al}_{2} \mathrm{O}_{3}$ sol (Nissan Chemical Industries, Ltd.) in ethanol. The molar ratio of $\mathrm{Al}_{2} \mathrm{O}_{3}: \mathrm{EtOH}$ was $1: 40$. The $\beta$-sialon substrate was dipped into the precursor solutions and withdrawn at a speed of $60 \mathrm{~mm} \mathrm{~min}^{-1}$. After the dip-coating, the sample was dried in air at room temperature for $1.5 \mathrm{~h}$ and heated in air at $600^{\circ} \mathrm{C}$ for $1 \mathrm{~h}$. The process of dipping to the heating was 6 times repeated (as-coated sample). The as-coated sample was heated at $1300^{\circ} \mathrm{C}$ in $\mathrm{Ar} / \mathrm{O}_{2}(95 / 5 \mathrm{vol} \%)$ for $2 \mathrm{~h}$ and subsequently treated in $\mathrm{Ar}$ for $10 \mathrm{~h}$ (heat-treated sample). The samples was oxidized in $\mathrm{Ar} / \mathrm{O}_{2} / \mathrm{H}_{2} \mathrm{O}\left(8 / 2 / 90\right.$ vol\%) at $1200^{\circ} \mathrm{C}$ for 24 $\sim 100 \mathrm{~h}$. Characterization of the samples was carried out by X-ray powder diffraction (XRD, RIGAKU RINT-2000), scanning electron microscope with energy dispersive analysis unit (SEM-EDS, JEOL JSM-6700F) and transmission electron microscope 
(TEM JEOL, JEM-2000ES) with EDS analysis unit.

\section{RESULTS AND DISCUSSION}

\section{3-1 As-coated sample}

Figure 1 shows SEM images of as-coated samples by using AK and CA precursors. Many cracks were observed at surface of the sample by using AK precursor (Fig. 1(a)). In contrast, few cracks were observed at surface by using CA precursor (Fig. 1(b)). Thickness of the $\mathrm{Al}_{2} \mathrm{O}_{3}$ films for both as-coated samples was about $1.5 \mu \mathrm{m}$, confirmed by cross-sectional images obtained by SEM observations. By XRD analysis, both samples gave no observable peak except for those of $\beta$-sialon, possibly due to a small amount and low crystallinity of coated $\mathrm{Al}_{2} \mathrm{O}_{3}$. However, the powders obtained by heating $\mathrm{AK}$ and $\mathrm{CK}$ precursors at $600^{\circ} \mathrm{C}$ for $1 \mathrm{~h}$ gave broad peaks corresponding to $\gamma-\mathrm{Al}_{2} \mathrm{O}_{3}$ (Fig. 2), showing that the coated alumina must be $\gamma$ - phase.

\section{3-2 Heat-treated sample}

Figure 3 shows the XRD patterns of heat-treated samples by using AK precursor. The heat-treatment was carried out for as-coated samples at $1300^{\circ} \mathrm{C}$ in $\mathrm{Ar} / \mathrm{O}_{2}(95 / 5 \mathrm{vol} \%)$ for $2 \mathrm{~h}$ and subsequently in $\mathrm{Ar}$ for $10 \mathrm{~h}$. In XRD pattern of the sample heated in $\mathrm{Ar} / \mathrm{O}_{2}$ for $2 \mathrm{~h}$ (Fig. 3 (a)), small peaks of cristobalite were observed in addition to the peaks of $\beta$-sialon substrate and $\alpha-\mathrm{Al}_{2} \mathrm{O}_{3}$. The observed cristobalite was formed by oxidation (eq. (1)). In the sample heated in $\mathrm{Ar} / \mathrm{O}_{2}$ atmosphere for $2 \mathrm{~h}$ and subsequently in Ar for 10 h (Fig. 3 (b)), peak intensity of cristobalite and $\alpha-\mathrm{Al}_{2} \mathrm{O}_{3}$ was decreased, whereas peaks of mullite were observed, suggesting that the cristobalite was reacted with coated alumina and was transformed to mullite. In the samples by using $\mathrm{CA}$ precursor, almost same patterns were observed by the heat-treatment at the corresponding conditions.

Figure 4 shows surface SEM images of the heat-treated samples using AK and CA precursors. No remarkable change was caused by the heat-treatment in the surface microstructure from that of corresponding as-coated samples shown in Fig. 1. However, small grains about $0.3 \mu \mathrm{m}$ long were observed in high-magnification images. These grains were not observed in as-coated samples. Figure 5 shows the cross-sectional TEM image of the heat-treated sample using CA precursor. At the surface, a dense layer was observed on the $\beta$-sialon substrate. Between the surface layer and $\beta$-sialon substrate, a white contrasted interlayer with about $200 \mathrm{~mm}$ thick was observed. From EDS analysis and XRD results (Fig. 3), the surface and the interlayer were mainly composed of $\alpha-\mathrm{Al}_{2} \mathrm{O}_{3}$ and mullite,
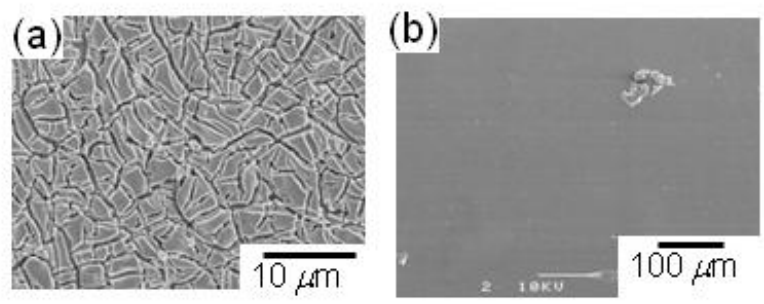

Fig. 1 Surface SEM images of as-coated samples by using (a) $\mathrm{AK}$ and (b) CA precursors.

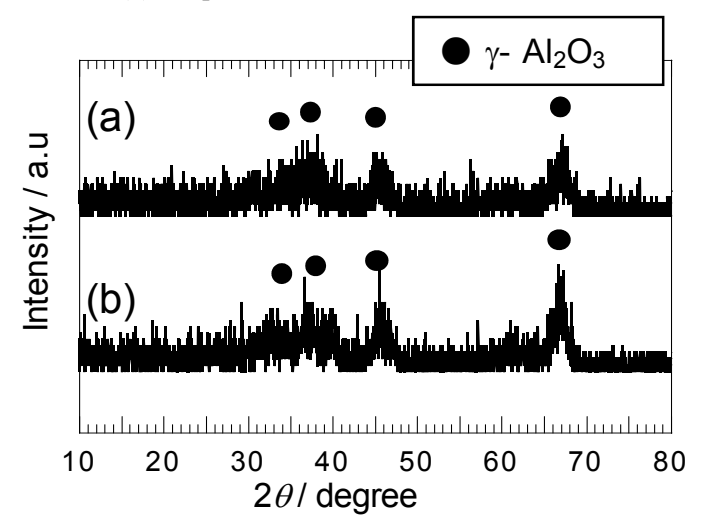

Fig. 2 XRD patterns of powders obtained by heating (a) AK and (b) CA precursors at $600{ }^{\circ} \mathrm{C}$ for $1 \mathrm{~h}$.

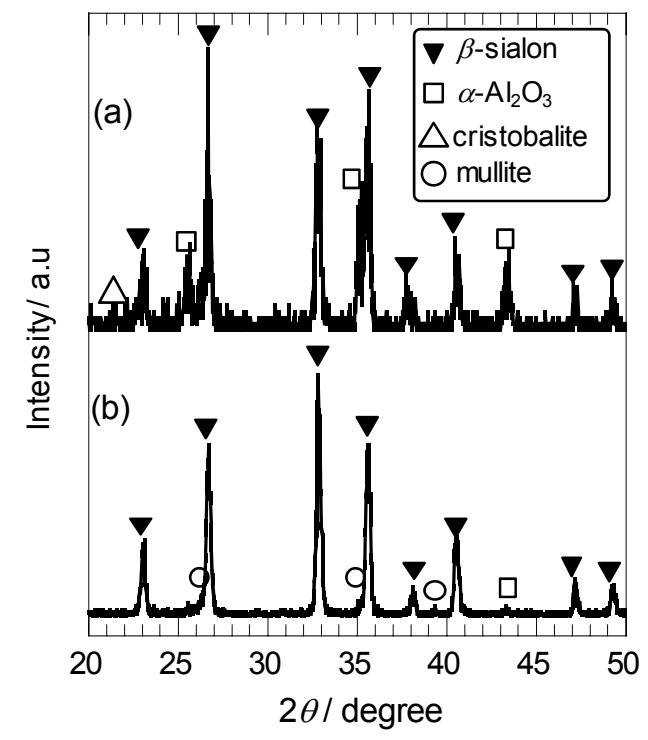

Fig. $3 \mathrm{XRD}$ patterns of the $\mathrm{Al}_{2} \mathrm{O}_{3}$ coated sample by using AK precursor heated (a) at $1300^{\circ} \mathrm{C}$ in $\mathrm{Ar} / \mathrm{O}_{2}$ $(95 / 5$ vol $\%)$ for $2 \mathrm{~h}$ and (b) subsequently treated in Ar for $10 \mathrm{~h}$.
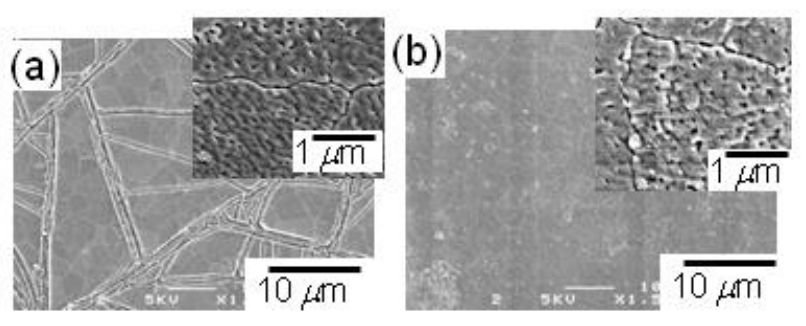

Fig. 4 Surface SEM images of samples samples by using (a) AK and (b) CA precursors. Inserts are the magnified images. 
respectively.

3-3 Oxidation in high $P_{\mathrm{H} 2 \mathrm{O}}$ atmosphere

Figure 6 shows the plot of weight gain of the samples due to oxidation with time at $1200^{\circ} \mathrm{C}$ in $\mathrm{Ar} / \mathrm{O}_{2} / \mathrm{H}_{2} \mathrm{O}(8 / 2 / 90$ vol\%) atmosphere. The weight gain of non-coated $\beta$-sialon ceramic at $100 \mathrm{~h}$ was 1.1 $\mathrm{mg} \mathrm{cm}{ }^{-2}$. This value is greater than the value (about $0.07 \mathrm{mg} \mathrm{cm}^{-2}$ ) reported in low $P_{\mathrm{H} 2 \mathrm{O}}$ atmosphere $\left(\mathrm{Ar} / \mathrm{O}_{2} / \mathrm{H}_{2} \mathrm{O}=80 / 10 / 10 \mathrm{vol} \%\right)$ at higher temperature of $1300^{\circ} \mathrm{C}$. ${ }^{5}$ The large weight gain in the present work demonstrated that the water vapor with high partial pressure significantly accelerate oxidation of $\beta$-sialon. The all $\mathrm{Al}_{2} \mathrm{O}_{3}$ coated samples decreased weight gains compared with non-coated $\beta$-sialon. The decrease of weight gain showed that $\mathrm{Al}_{2} \mathrm{O}_{3}$ coating improves oxidation resistance, irrespective of the crystallinity of the coating. The weight gain of heat-treated samples by using AK and CA precursors were similar to each other and were slightly smaller than those of as-coated samples.

Figure 7 shows XRD patterns of samples oxidized for $50 \mathrm{~h}$. The pattern of oxidized non-coated sample brings about broad and small peaks of mullite and $\beta$-sialon. The decreasing of peak intensity is due to a formation of oxidation products mainly amorphous $\mathrm{SiO}_{2}$ on the $\beta$-sialon substrate. The as-coated samples by using $\mathrm{AK}$ precursor give peaks of mullite and cristobalite in addition to peaks of $\beta$-sialon, showing that the $\beta$-sialon is oxidized following the equation (1). Compared with the pattern of non-coated sample, the peaks of $\beta$-sialon and mullite were larger and clearly seen in the pattern of as-coated sample. This indicates that the amount of oxidation products formed on sample was smaller than that on non-coated sample. The samples with heat-treatment ((Fig. 7 (c)) gave smaller peaks of mullite and cristobalite than those of as-coated samples. Decrease of peak intensity of mullite and cristobalite showed that the oxidation resistance is improved by the heat-treatment. Similar patterns were obtained in the samples by using CA precursor.

Figure 8 shows the surface and cross sectional images of oxidized samples. The samples were as-coated and heat-treated ones by using AK sol. In as-coated sample, surface became rough and some pores shown by arrow were appeared, compared with the sample before oxidation (shown in Fig. 1 (a)). The surface consisted of grains, which are clearly seen in high magnification images. Although no obvious difference was observed between areas of (i) and (ii), they were corresponding to the $\mathrm{Al}_{2} \mathrm{O}_{3}$ and mullite, respectively, confirmed by EDS analysis. The former is remnant of the alumina coating and the latter is formed by oxidation of $\beta$-sialon or the reaction

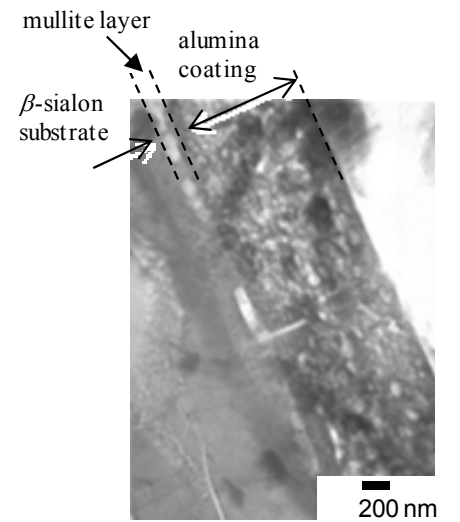

Fig. 5 Cross-sectional TEM image at the interface between alumina coating and $\beta$-sialon substrate. The sample is heat-treated oneby using CA precursor.

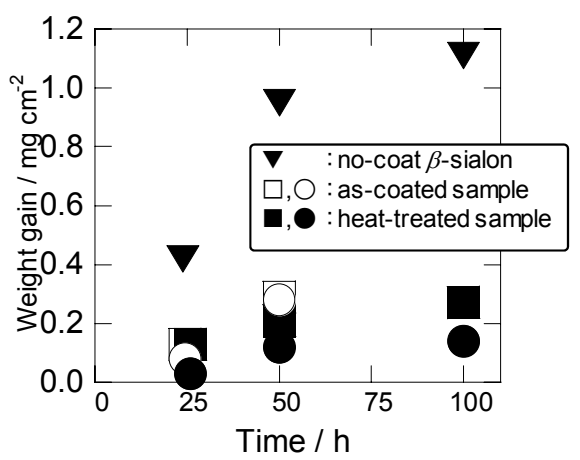

Fig. 6 P lots of weight gains due to oxidation in $\mathrm{H}_{2} \mathrm{O} / \mathrm{O}_{2} / \mathrm{Ar}(90 / 2 / 8 \mathrm{kPa})$ atmosphere at $1200^{\circ} \mathrm{C}$. Marks of square and circle denote the sampleby using $\mathrm{AK}$ and CA precursors, respectively.

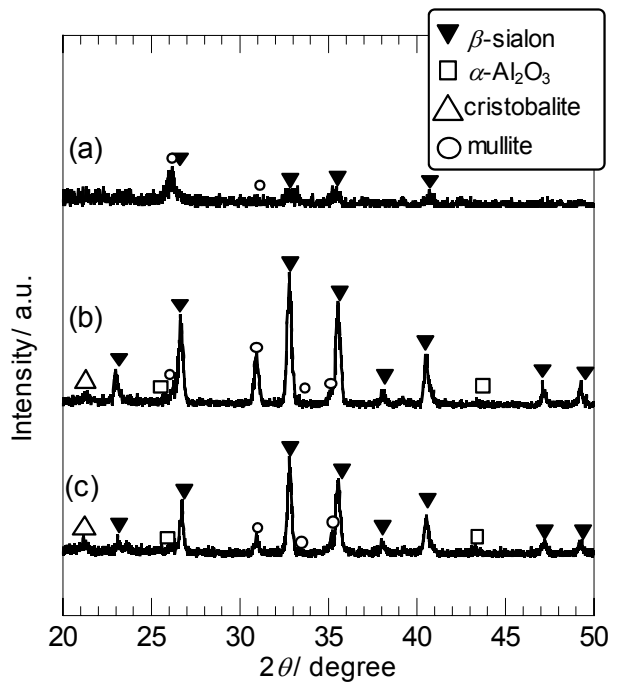

Fig. 7 Surface XRD patterns of the oxidized samples. (a) nocoat $\beta$-sialon, (b) as-coated and (c) heat-treated samples by using $\mathrm{AK}$ precursor.

between coated $\mathrm{Al}_{2} \mathrm{O}_{3}$ and $\mathrm{SiO}_{2}$ formed by oxidation of $\beta$-sialon. In the heat-treated sample (Fig. 8 (b)), the microstructure of the surface was similar to that of the sample before oxidation (Fig. 4 (a)). From the EDS analysis, the surface layer was composed of alumina. 
However, from the cross sectional observation (Fig. 8 (c)), the thickness of the alumina coating was decreased to $0.5 \mu \mathrm{m}$ from that of non-oxidized sample $(1.5 \mu \mathrm{m})$ and an interlayer about $3 \mu \mathrm{m}$ thick possibly due to oxidation products was observed between surface layer and $\beta$-sialon substrate. The formation of the interlayer suggests that water and/or oxygen diffuse through the alumina coating and oxidize $\beta$-sialon substrate. The mullite layer, which was observed in the sample before oxidation, was disappeared in the oxidized sample.

Since the alumina coating remained at surface in the heat-treated sample, the heat-treatment is effective to improve oxidation resistance possibly due to the high chemical stability of $\alpha-\mathrm{Al}_{2} \mathrm{O}_{3}$ comparing with $\gamma-\mathrm{Al}_{2} \mathrm{O}_{3}$. Because almost same results were obtained in the sample by using CA precursor, oxidation resistance is influenced not by the microstructure but by the crystalline phase of the alumina coating.

\section{SUMMARY}

$\mathrm{Al}_{2} \mathrm{O}_{3}$ thin film was formed as EBC on the surface of $\beta$-sialon ceramics by dip-coating method of alkoxide $(\mathrm{AK})$ and alumina sol (CA) precursors and heating at $600^{\circ} \mathrm{C}$ for $1 \mathrm{~h}$ in air (as-coated sample). The thickness of the coated film was about $1.5 \mu \mathrm{m}$. Cracks were formed in the film fabricated by using AK precursor but the formation of cracks was restrained by using $\mathrm{CA}$ precursor. As-coated samples were heat-treated at $1300^{\circ} \mathrm{C}$ in $\mathrm{Ar} / \mathrm{O}_{2}(95 / 5$ vol.\%) for $2 \mathrm{~h}$ subsequently in $\mathrm{Ar}$ for $10 \mathrm{~h}$ (heat-treated sample). By the heat-treatment, crystalline phase of coated $\mathrm{Al}_{2} \mathrm{O}_{3}$ was changed from $\gamma$ - to $\alpha$-phase and thin mullite layer was formed between $\mathrm{Al}_{2} \mathrm{O}_{3}$ coating and $\beta$-sialon substrate. From the oxidation test in $\mathrm{Ar} / \mathrm{O}_{2} / \mathrm{H}_{2} \mathrm{O}(8 / 2 / 90 \mathrm{vol} \%)$ at $1200^{\circ} \mathrm{C}, \mathrm{Al}_{2} \mathrm{O}_{3}$ coated samples showed high oxidation resistance comparing with no-coated samples. Among the $\mathrm{Al}_{2} \mathrm{O}_{3}$ coated samples, the heat-treated samples showed highest oxidation resistance. After the oxidation test for $50 \mathrm{~h}$, alumina coating was left on the surface of the $\beta$-sialon substrate, showing that the coating of $\alpha-\mathrm{Al}_{2} \mathrm{O}_{3}$ effectively acts as an EBC to the high $P_{\mathrm{H} 2 \mathrm{O}}$ atmosphere.

\section{REFERENCES}

1. T. Ekstrom and M. Nygren, J. Am. Ceram. Soc., 75,259-276 (1992).

2. N. S. Jacobson, J. Am. Ceram. Soc., 76, 3-28

(1993)

3. D. J. Choi, D. B. Fischbach and W. D. Scott, J.

Am. Ceram. Soc., 72, 1118-23 (1989).

4. E. J. Opila, J. Am. Ceram. Soc., 77, 730-36

(1994)
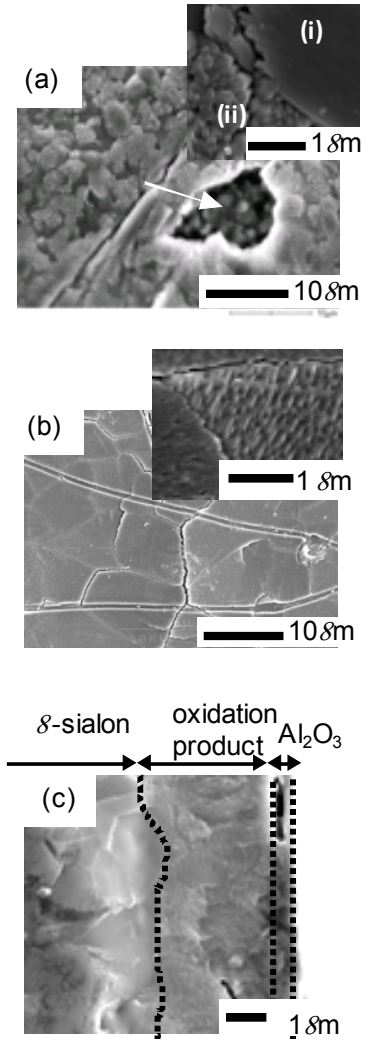

Fig. 8 Surface and cross-sectional SEM images of oxidized samples by using AK sol. Surface of (a) as-coated and (b) heat-treated samples and (c) cross section of (b). The samples were oxidized for $50 \mathrm{~h}$ in $\mathrm{Ar} / \mathrm{O}_{2} / \mathrm{H}_{2} \mathrm{O}$ (8/2/90 vol.\%) atmosphere. Inserts are high magnification images.

5. H. Kiyono and S. Shimada, Key. Eng. Mater., 264-268, 893-896 (2004).

6. H. Kiyono S. Shimada and K. J. D. MacKenzie, J. Elec. Soc., 148, B86-B91 (2001).

7. K. N. Lee, Surf. Coat. Tech., 133-134, 1-7 (2000).

8. I. Tsarenko, H. H. Du and W. Y. Lee, J. Am.

Ceram. Soc., 87, 417-420 (2004).

9. J. Persson and M. Nygren, J. Eur. Ceram. Soc., 13, 467-484 (1994).

(Received January 25, 2010; Accepted July 1, 2010) 